\title{
Perbandingan Filter Shen-Castan, Canny-Deriche dan Madenda untuk Citra Digital dengan Gangguan Blur
}

\author{
Widya Khafa Nofa ${ }^{1}$, Dewi Anggraini Puspa Hapsari ${ }^{2}$ \\ ${ }^{1}$ Program Studi Manajemen Universitas Gunadarma \\ ${ }^{2}$ Program Manajemen Fakultas Ekonomi Universitas Gunadarma \\ E-mail: ${ }^{1}$ widyakhafa@gmail.com, ${ }^{2}$ dewi.anggraini.puspa@gmail.com
}

\begin{abstract}
Abstrak
Dengan adanya gangguan noise, dapat mengakibatkan informasi dalam suatu citra menjadi tidak jelas. Selain itu jika noise muncul pada area tepian objek dapat mengakibatkan tepian dari objek menjadi buram dan tidak beraturan serta memungkinkan terjadi pergeseran posisi tepi. Sehingga diperlukan penghilangan atau penghalusan noise pada citra digital tersebut. Filter IIR adalah jenis filter yang memiliki sistem feedfoward dan feedback sekaligus. Hal ini berarti hasil keluaran dari IIR tidak hanya tergantung pada data sesaat dan data sebelumnya tetapi juga tergantung pada hasil perhitungan sebelumnya. Sehingga untuk citra bernoise diharapkan citra IIR dapat lebih optimal dalam melakukan pendeteksian tepi. Ada beberapa algoritma dalam filter IIR, diantaranya filter Shen-Castan, Canny-Deriche dan Madenda. Tujuan dari penelitian ini adalah untuk membandingkan performa dari filter Shen-Castan, filter Canny-Deriche dan filter Madenda dalam melakukan pendeteksian tepi untuk citra dengan gangguan blur. Penelitian dilakukan dengan menerapkan ketiga filter untuk pendeteksian tepi citra yang mengalami gangguan noise. Dari perbandingan ketiga filter tersebut menunjukkan bahwa filter Canny-Deriche dapat menghasilkan deteksi tepi yang lebih baik dibandingkan filter Madenda dan filter Shen-Castan dimana intensitas tepi objek lebih tinggi dibandingkan dengan intensitas noise yang terfilter.
\end{abstract}

Kata Kunci-Citra dengan gangguan blur, filter Shen-Castan, filter Canny-Deriche, filter Madenda

\begin{abstract}
With noise disturbance, it can cause information in an image to become unclear. Besides, if noise appears on the edge area of the object may cause the edges of the object to become blurry and irregular and allow for a shift in the position of the edges. So it is necessary to remove or fine-tuning the noise in the digital image. IIR filter is a type of filter that has a feedfoward and feedback system at the same time. This means that the output of IIR depends not only on the momentary data and the previous data but also depends on the results of the previous calculation. So for an inoise image, it is expected that IIR imagery can be more optimal in performing edge detection. There are several algorithms in IIR filters, including Shen-Castan, Canny-Deriche and Madenda filters. The purpose of this study was to compare the performance of Shen-Castan filters, Canny-Deriche filters and Madenda filters in performing edge detection for imagery with blur interference. The research was conducted by applying all three filters for the detection of edges of imagery that are experiencing noise disturbances. The comparison of the three filters shows that Canny-Deriche filters can produce better edge detection compared to Madenda filters and Shen-Castan filters where the intensity of the object's edges is higher than the filtered noise intensity.
\end{abstract}

Keywords - Image with blur interference, the Shen-Castan filter, the Canny-Deriche filter, Madenda filter 


\section{PENDAHULUAN}

Citra yang dihasilkan dari sebuah alat perekam terkadang tidak selamanya merepresentasikan hasil yang baik. Kualitas yang dihasilkan oleh sebuah kamera dapat mengalami gangguan derau (noise). Derau (noise) adalah gangguan yang muncul secara acak dan dapat mengakibatkan nilai piksel-piksel dalam sebuah citra mengalami perubahan intensitas warna secara acak pula [1]. Dengan adanya gangguan noise, dapat mengakibatkan informasi dalam suatu citra menjadi tidak jelas. Selain itu jika noise muncul pada area tepian objek dapat mengakibatkan tepian dari objek menjadi buram dan tidak beraturan serta memungkinkan terjadi pergeseran posisi tepi [2]. Hal ini dapat mengakibatkan kehilangan informasi penting yang terkandung di dalam citra.

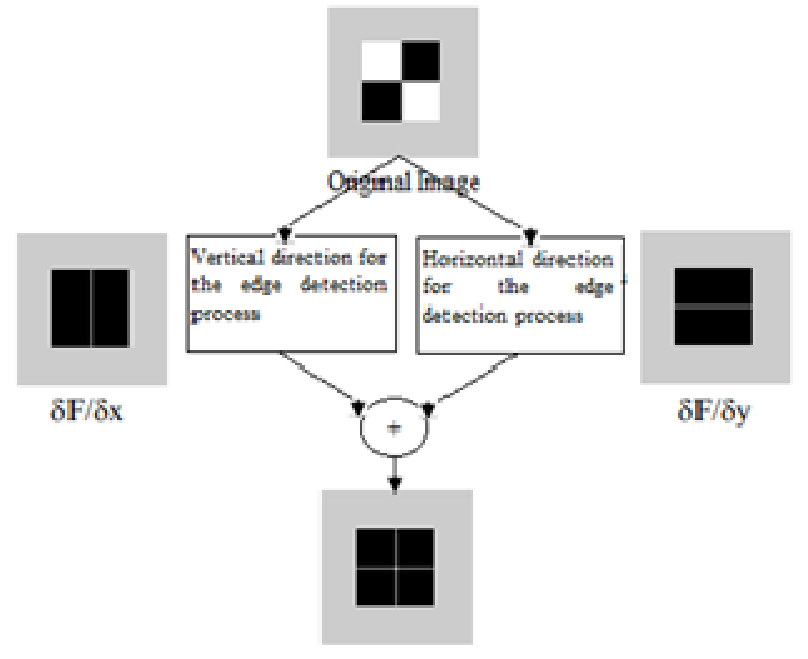

Gambar 1 Proses dari deteksi tepi

Dalam bidang computer vision, pendeteksian tepi merupakan salah satu pengolahan dasar citra yang penting. Dengan proses ini, tepi batas dari sebuah objek (foreground) dengan latar belakangnya (background) dapat ditentukan dengan baik. Tepi batas dalam citra merupakan perbedaan intensitas atau warna antara satu piksel dengan piksel tetangga terdekatnya[3]. Untuk dapat melakukan pendeteksian tepi obyek dalam kondisi citra bernoise maka harus terlebih dahulu dilakukan penghilangan atau penghalusan noise [4]. Penghilangan atau penghalusan noise pada citra digital disebut dengan pemfilteran. Filter yang digunakan dalam untuk melakukan penghalusan noise adalah tipe filter low-pass. Menggunakan tipe filter low-pass dikarenakan noise yang berada pada citra pada umumnya berada pada frekuensi tinggi.

Dalam pengolahan citra digital terdapat dua jenis filter yaitu FIR (Finite Impulse Response) dan IIR (Infinite Impulse Response). FIR merupakan jenis filter yang memiliki respon impuls terbatas. Hasil output dari FIR adalah sebuah linier invarian waktu yang merupakan konolusi antara sinyal masukan dengan koefisien respons impuls filter. Filter FIR sering disebut juga dengan filter nonrecursive, yang artinya hanya memiliki umpan maju (feedfoward) dan tidak memiliki sistem umpan balik (feedback). Sedangkan filter IIR adalah jenis filter yang memiliki sistem feedfoward dan feedback sekaligus. Hal ini berarti hasil keluaran dari IIR tidak hanya tergantung pada data sesaat dan data sebelumnya tetapi juga tergantung pada hasil perhitungan sebelumnya. Sehingga untuk citra bernoise diharapkan citra IIR dapat lebih optimal dalam melakukan pendeteksian tepi. Ada beberapa algoritma pada filter IIR yang telah dikembangkan dalam pengolahan citra dimana masing-masing didasarkan pada karakteristik citra yang dianalisis. Diantaranya dikenal filter Shen-Castan, CannyDeriche dan Madenda.

Filter Shen-Castan merupakan filter yang terdiri dari satu pasang (fungsi 1 dimensi/1D) [5]. Filter Canny-Deriche dikembangkan menggunakan algoritma multi-tahap untuk mendeteksi berbagai tepi dalam citra. Algoritma ini mengacu pada tiga buah kriteria John F. Canny yaitu good detection, good localization dan one response to one [6][2]. Berdasarkan pada kombinasi dari ketiga kriteria ini, Canny-Deriche mampu secara matematis menurunkan dua filter. Sedangkan filter Madenda, merupakan pengembangan dari filter Shen-Castan dan Canny-Derieche dengan mengatur 
parameter $\beta$ sebagai parameter pengatur gangguan blur menjadi lebih besar hingga mendekati satu [7].

Penelitian sebelumnya yang telah dilakukan adalah : Dewi dan Widya pada tahun 2020, melakukan perbandingan algoritma Shen-Castan dan algoritma Canny-Deriche untuk citra dengan gangguan blur (buram) pada citra asli [5]. Pengujian dengan dilakukan proses mengaburkan citra dengan rata-rata piksel dengan delapan piksel tetangganya. Hal ini dimaksudkan untuk memberikan gangguan efek blur. Kemudian melakukan proses pendeteksian tepi dengan menggunakan algoritma Shen-Castan dan algoritma Canny-Deriche. Hasil pengujian menunjukkan bahwa algoritma CannyDeriche cukup mampu dengan jelas mendeteksi tepi citra walau citra uji mengalami gangguan efek buram dibandingkan dengan algoritma Shen-Castan dimana intensitas tepi objek lebih tinggi dibandingkan dengan intensitas noise yang terfilter. Sugeng, Dewi dan Romdhoni pada tahun 2020 [8], membuktikan tentang performa dari algoritma Madenda untuk citra dengan gangguan blur. Pengujian dilakukan dengan proses mengaburkan citra terlebih dahulu dengan bantuan imfilter. Kemudian selanjutnya dilakukan deteksi tepi pada citra tersebut. Hasilnya menunjukkan jika filter Madenda dapat mendeteksi tepi dari citra dengan gangguan blur tersebut namun dengan parameter pengatur blur $(\beta)$ maksimal adalah 1 .

Berdasarkan pada penjabaran di atas maka tujuan dari penelitian ini adalah untuk membandingkan performa dari filter Shen-Castan, filter Canny-Deriche dan filter Madenda dalam melakukan pendeteksian tepi untuk citra dengan gangguan blur.

\section{METODE PENELITIAN}

Metode yang digunakan dalam penelitian ini adalah metode pengumpulan data. Dimana sebelum melakukan pengujian maka dilakukan pengumpulan data citra asli tanpa gangguan blur yang akan digunakan sebagai objek deteksi tepi. Penelitian juga dilakukan dengan mempelajari buku-buku yang terkait dengan deteksi tepi, filter Shen-Castan, filter Canny-Deriche dan filter Madenda. Kemudian juga mempelajari tools yang akan digunakan yaitu MATLAB (versi trial) untuk proses pendeteksian tepi. Penelitian dilakukan dengan menerapkan filter Shen-Castan, filter Canny-Deriche dan filter Madenda untuk pendeteksian tepi objek. Pendeteksian tepi dilakukan dengan membandingkan hasil dari tebal dan tipis garis tepi yang dihasilkan dari masing-masing. Adapun alur tahapan penelitian ini dapat dilihat pada gambar 1 di bawah ini :

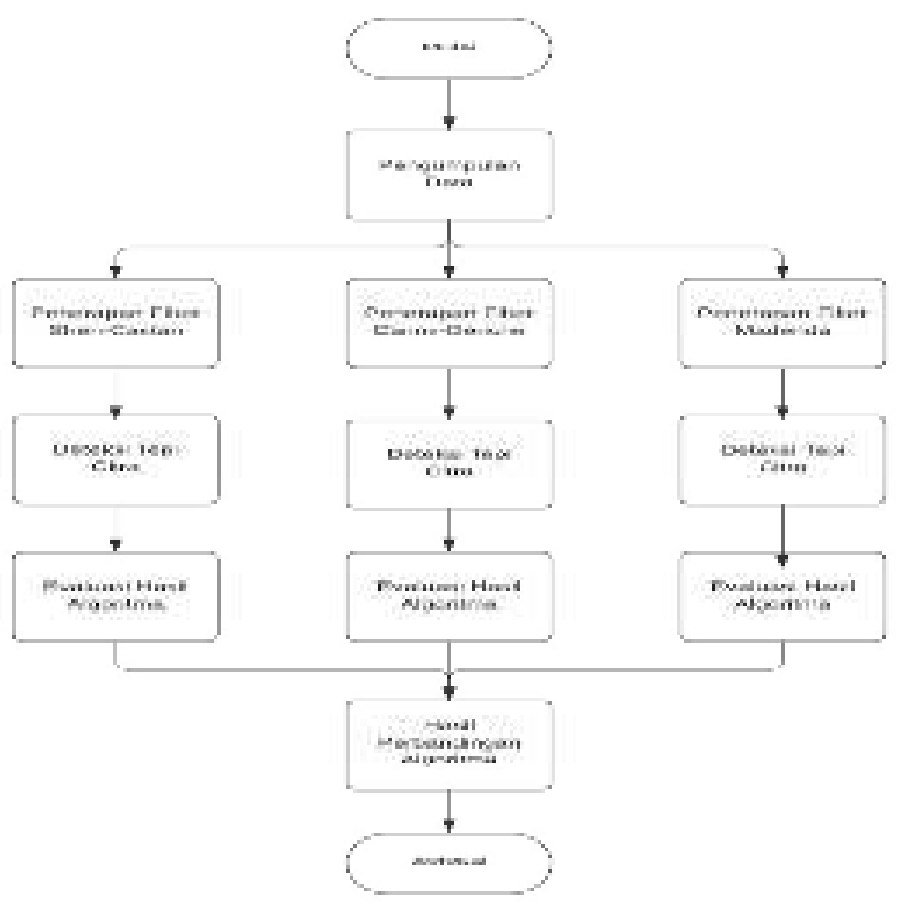

Gambar 2. Alur Tahap Penelitian 


\section{Konsep Filter Canny-meriche}

Filter Canny-Deriche yang dikembangkan oleh Rachid Deriche mengacu pada 3 buah kriteria John F. Canny yaitu good detection, good localization dan one response to one edge [9]. Good detection berarti filter dapat mengoptimasi pendeteksian tepi yang sebenarnya dan meminimalkan pendeteksian tepi bayangan akibat pengaruh munculnya noise di sekitar tepi. Kriteria ini bertujuan memaksimalkan signal to noise rasio (SNR). Good localization artinya posisi tepi yang terdeteksi oleh filter yang harus sesuai atau sedekat mungkin dengan posisi tepi yang sebenarnya. Sedangkan one response to one edge artinya filter harus dapat mendeteksi hanya satu titik untuk satu tepi [4].

Berdasarkan dari kriteria tersebut filter ini mampu secara matematis menurunkan dua filter yaitu filter $\mathrm{h}(\mathrm{x})$ sebagai penghalus noise (smoothing filter) dan filter $\mathrm{f}(\mathrm{x})$ sebagai pendeteksi tepi (derivative filter) [4].

$$
\begin{aligned}
& \mathrm{h}(\mathrm{x})=\mathrm{K}(\alpha|\mathrm{x}|+1) \mathrm{e}^{\wedge}(-\alpha|\mathrm{x}|) \\
& \mathrm{f}(\mathrm{x})=-\mathrm{Cxe}^{\wedge}(-\alpha|\mathrm{x}|)
\end{aligned}
$$

Parameter $\alpha$ sebagai parameter penentu seberapa halus noise akan difilter. $\mathrm{K}$ dan $\mathrm{C}$ adalah konstanta normalisasi. Sinyal keluaran y(n) dari sistem dengan respons impuls dari masingmasing filter $\mathrm{h}(\mathrm{x})$ dan $\mathrm{f}(\mathrm{x})$ terhadap sinyal masukan $\mathrm{x}(\mathrm{n})$.

Adapun pseudocode untuk Filter Canny-Deriche adalah :

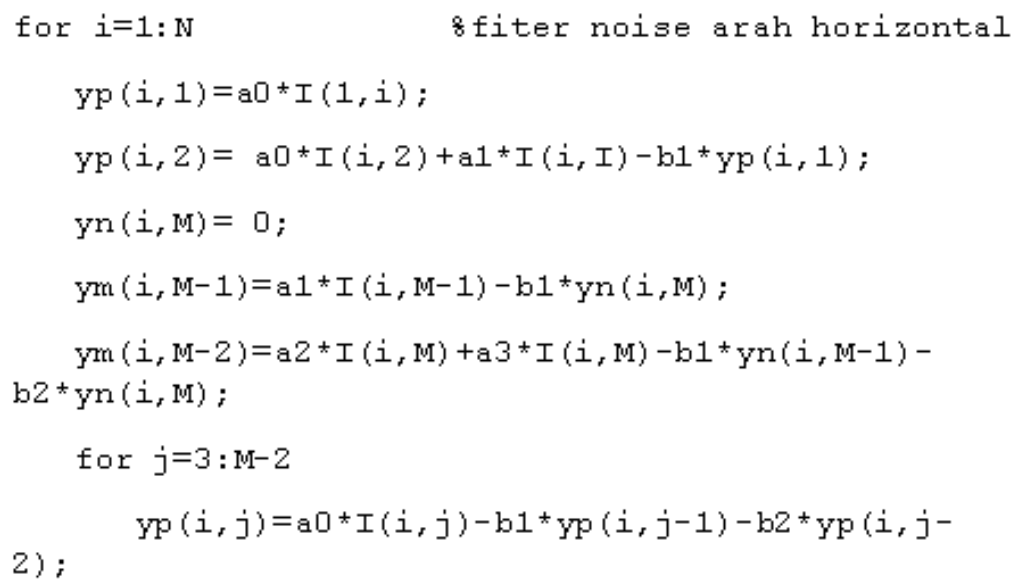

Pseudo-code di atas merupakan implementasi untuk filter Canny-Deriche untuk pedeteksian tepi. Mengingat bahwa citra merupakan fungsi 2-D maka operasi pemfilteran noise dan operasi pendeteksian tepi dilakukan secara terpisah dan dengan arah sumbu koordinat yang berbeda.

\section{Konsep Filter Shen-Castan}

Filter Shen-Castan yang dikembangkan oleh Jun Shen dan Serge Castan adalah penyempurnaan konsep Canny-Deriche [2]. Tujuan dari filter Shen-Castan adalah mengoptimalkan pendeteksian tepi pada citra bernoise serta meminalkan waktu komputasi dan biaya implementasinya dalam bentuk rangkaian elektronika.

Shen-Castan memiliki pendapat yang sama dengan Canny di pendekatan untuk deteksi tepi yang merupakan konvolusi dengan kernel yang menghaluskan dan diikuti dengan pencarian tepi citra. Hal ini bertujuan untuk meningkatkan presisi lokalisasi ketika mendeteksi kontur. Kontur yang dihasilkan oleh metode ini lebih tipis daripada Canny-Deriche. Operator ini sangat efektif untuk mendeteksi kontur horizontal dan vertikal tetapi dalam kontur diagonal menghasilkan output yang lebih rendah.

Fungsi ini terdiri dari satu pasang dan merupakan fungsi 1 dimensi (1-D) dimana fungsi matematikanya diberikan pada persamaan berikut ini [4]:

$$
\begin{aligned}
& \mathrm{f}(\mathrm{x})=\mathrm{Ce}^{-\alpha .|x|} \\
& \mathrm{h}(\mathrm{x})=\mathrm{K} \cdot \mathrm{e}^{-\alpha .|x|}, \text { jika } \mathrm{x}<0 \\
& \quad-\mathrm{K} \cdot \mathrm{e}^{-\alpha .|x|}, \text { jika } \mathrm{x} \geq 0
\end{aligned}
$$

dimana $C=\left(1-\mathrm{e}^{-\alpha}\right) /\left(1+\mathrm{e}^{-\alpha}\right)$ dan $\mathrm{K}=1-\mathrm{e}^{-\alpha}$ merupakan konstanta normalisasi dari fungsinya masing-masing. 
Fungsi $\mathrm{f}(\mathrm{x})$ yang ada pada filter ini berperan sebagai filter low-pass yang ditujukan untuk memfilter noise, sedangkan fungsi $\mathrm{h}(\mathrm{x})$ merupakan filter band-pass yang berperan sebagai pendeteksi tepi citra.

Adapun pseudocode untuk Filter Shen Castan adalah :

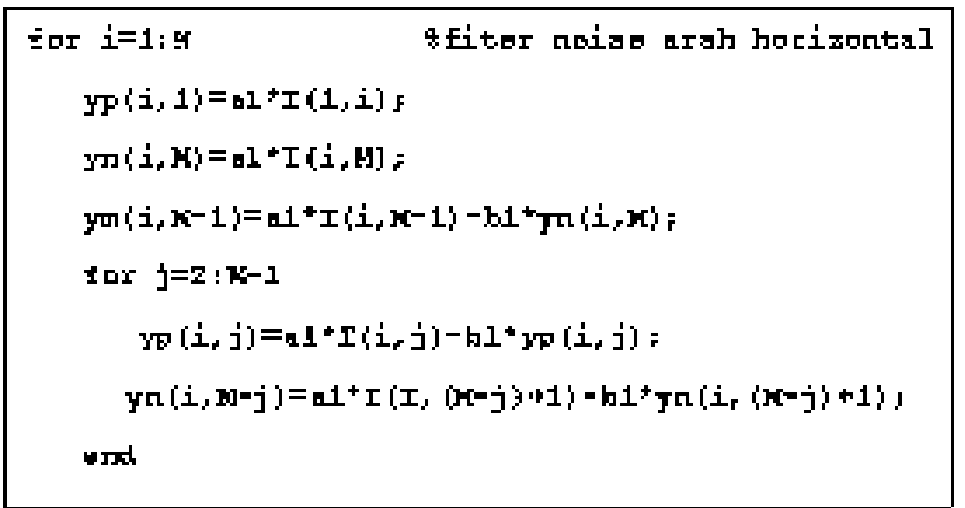

Pseudo-code di atas merupakan implementasi untuk filter Shen-Castan untuk pedeteksian tepi. Mengingat bahwa citra merupakan fungsi 2-D maka operasi pemfilteran noise dan operasi pendeteksian tepi dilakukan secara terpisah dan dengan arah sumbu koordinat yang berbeda.

\section{Konsep Filter Madenda}

Filter Madenda mengacu pada filter Canny-Deriche dan filter Shen-Castan namun perbedaan terletak pada parameter pengatur gangguan blur $(\beta)$. Persamaan fungsi matematika dari kedua filter adalah sebagai berikut :

$$
\begin{aligned}
& f(x)=-K_{1} x e^{-\alpha x}\left(1-\cos (\alpha \beta|x|)+\frac{\left(1-\beta^{2}\right)}{2 \beta} \sin (\alpha \beta|x|)\right) \\
& h(x)=-K_{2} e^{-\alpha}|x|\left(1-\frac{1}{2} \cos (\alpha \beta|x|)+\frac{1}{2 \beta} \sin (\alpha \beta|x|)\right)
\end{aligned}
$$

Dalam kedua persamaan fungsi matematika di atas terdapat parameter noise yaitu parameter $\alpha>$ 0 sama seperti dalam filter Shen-Castan dan filter Canny-Deriche. Parameter $\beta(0>\beta>1)$ merupakan parameter pengatur blur. Untuk citra tanpa gangguan blur maka nilai dari $\beta$ dapat diatur mendekati 0 . Sedangkan bila terdapat blur maka nilai $\beta$ diatur lebih besar hingga mendekati satu.

Sinyal keluaran y(n) sebagai respon impuls masing-masing filter dianggap sinyal masukkan $\mathrm{x}(\mathrm{n})$ sehingga didapatkan sinyal keluaran sebagai berikut [8]:

1. Persamaan fungsi matematika untuk sinyal keluaran filter $\mathrm{f}(\mathrm{x})$

$$
\begin{aligned}
& y^{\prime}(n)=c_{1} x(n-1)+c_{1}^{x(n-2)-b_{1} y^{*}(n-1)-b_{2} y^{*}(n-2)-b_{1} y^{*}(n-3)} \\
& y^{-}(n)=c_{0} x(n+1)+c_{1} x(n+2)-b_{1} y^{-}(n+1)-b_{2} y^{\prime}(n+2)-b_{1} y^{\prime}(n+3) \\
& \begin{array}{l}
y(n)=y(n)-y(n) \\
\text { dimand }
\end{array} \\
& K_{1}=\frac{1+(1+2 \cos (\alpha \beta))\left(e^{-3+\infty}-e^{5}\right)-e^{-3 \pi}}{1+\beta^{3}} \\
& (1-\cos (\alpha \beta))\left(e^{-\alpha}+e^{-2 \alpha}\right)+\frac{\left(1-\beta^{2}\right)}{2 \beta} \sin (\alpha \beta)\left(e^{-\alpha}-e^{-2 \alpha}\right) \\
& c_{0}=K_{1} e^{-x}\left(1-\cos (\alpha \beta)+\frac{\left(1-\beta^{2}\right)}{2 \beta} \sin (\alpha \beta)\right) \\
& c_{2}=K_{1} e^{-2 \alpha\left(1-\cos (\alpha \beta)-\frac{\left(1-\beta^{2}\right)}{2 \beta} \sin (\alpha \beta)\right)}
\end{aligned}
$$




$$
\begin{aligned}
& b_{1}-e^{-e}\left(1+2 \cos \left(a^{2}\right)\right)
\end{aligned}
$$

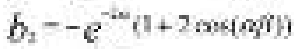

$$
\begin{aligned}
& b_{0}=e^{\text {*t }}
\end{aligned}
$$

2. Persamaan fungsi matematika untuk sinyal keluaran filter $\mathrm{h}(\mathrm{x})$

$$
\begin{aligned}
& y^{*}(v)=a(n)+a(n-1)+a^{2}(n-2)-b y^{*}(n-b)-b y(n-2)-b y(n-3) \\
& \left.y(n)=a^{\text {x(n+1) }}+a^{\text {(n) }}+2\right)+a^{x(n+3)}-b y(n+1)-b y(n+2)-b y(n+3) \\
& \text { ydimana }{ }^{n)-y(n)}
\end{aligned}
$$

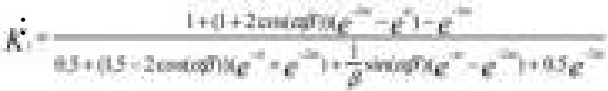

$$
\begin{aligned}
& a_{1}=0.5 \mathrm{~K}
\end{aligned}
$$

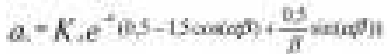

$$
\begin{aligned}
& a_{z}=K_{2} e^{-2 \operatorname{si}}\left(1-0,5 \cos (\alpha \beta)-\frac{03}{\beta} \sin (\alpha \beta)\right) \\
& a_{2}=K_{2} e^{-\alpha}\left(1-0,5 \cos (\alpha \beta)+\frac{0,5}{\beta} \sin (\alpha \beta)\right) \\
& a_{\mathrm{t}}=K_{i} e^{-\pi\left(0,5-1,5 \cos (\alpha \beta)-\frac{0,5}{\beta} \sin (\omega \beta)\right)} \\
& a_{5}=0,5 K_{2} e^{-30} \\
& b_{1}=-e^{-\pi}(1+2 \cos (\omega \beta)) \\
& b_{2}=-e^{-j i \pi}(1+2 \cos (\alpha \beta)) \\
& b_{1}=-e^{-3 n}
\end{aligned}
$$

Dari dua persamaan ini menunjukkan bahwa kedua filter merupakan filter rekursif IIR orde tiga. Adapun pseudo-code untuk Filter Madenda adalah :

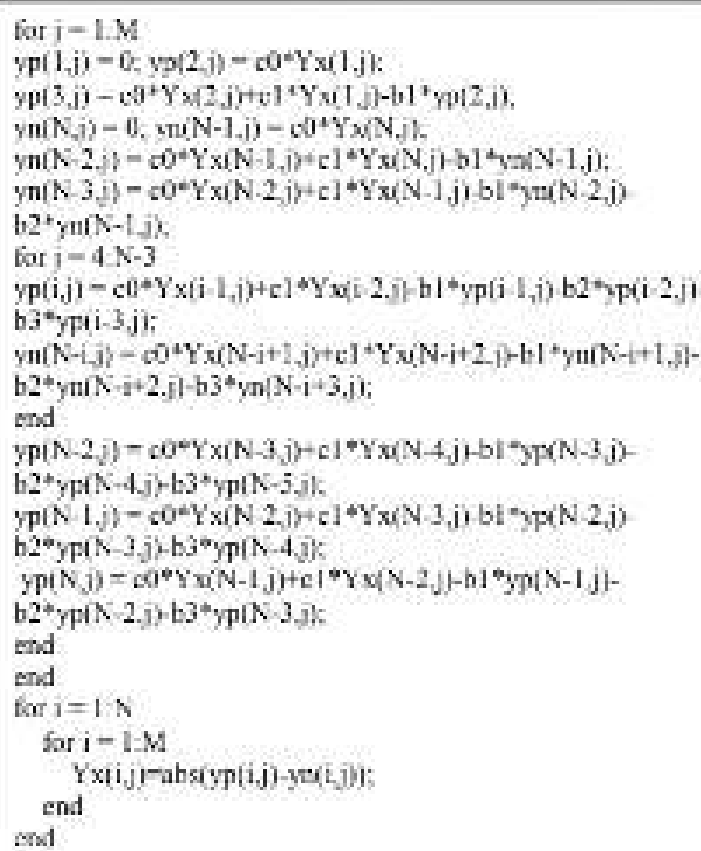

Pseudo-code di atas merupakan implementasi untuk filter Madenda untuk pedeteksian tepi. Mengingat bahwa citra merupakan fungsi 2-D maka operasi pemfilteran noise dan operasi pendeteksian tepi dilakukan secara terpisah dan dengan arah sumbu koordinat yang berbeda. 


\section{HASIL DAN PEMBAHASAN}

Penelitian ini membandingkan tiga buah filter deteksi tepi, yaitu filter Canny-Deriche, filter Shen-Castan dan filter Madenda. Deteksi tepi yang akan digunakan pada penelitian ini citra dengan menggunakan citra asli berbentuk jpeg yang diambil dari sumber internet. Adapun citra asli yang digunakan untuk pengujian adalah sebagai berikut :

Tabel 1. Citra Asli (Sumber : Internet)

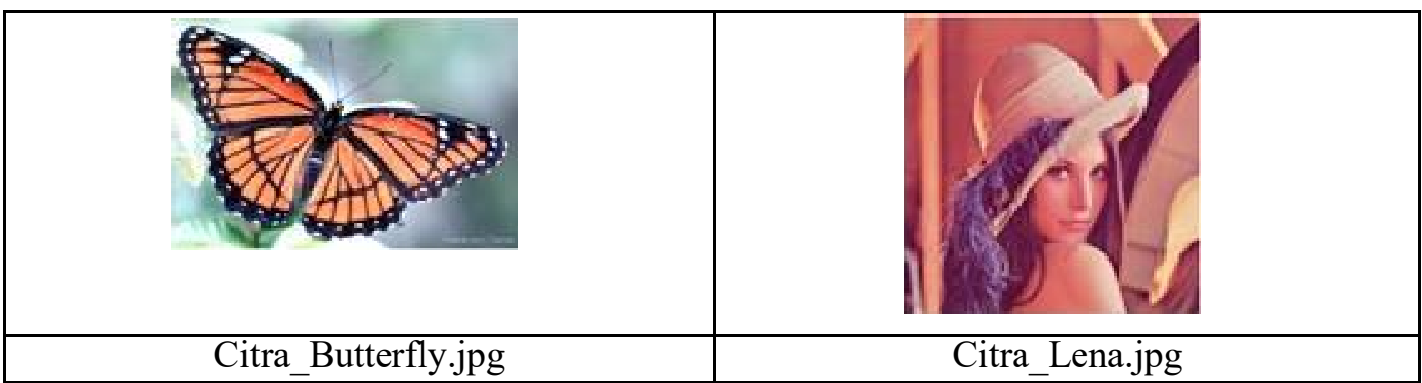

Dari kedua citra ini maka dilakukan proses simulasi gangguan noise dengan menggunakan tools MATLAB. Simulasi gangguan noise pada citra mengunakan proses mengaburkan citra dengan rata-rata piksel dengan delapan piksel tetangganya (neighbor). Hal ini dimaksudkan untuk memberikan gangguan efek blur pada citra asli.

1. Kode program untuk Citra butterfly

rgblmage = imread ('Citra Butterfly.jpg'); \% Sample image.

windowWidth $=13$; $\frac{\circ}{0}$ Whatever you want. More blur for larger

numbers. kernel $=$ ones (windowWidth) $/$ windowWidth $\wedge 2$;

blurredImage = imfilter(rgbImage, kernel); $\frac{\circ}{\circ}$ Blur the

image. imshow(blurredImage); 응 Display it.

Dari kode program ini maka dihasilkan citra modifikasi sebagai berikut :

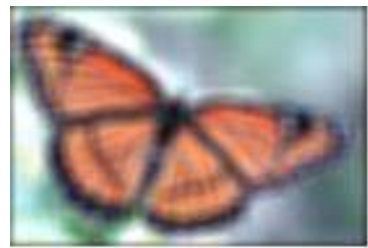

Gambar 3. Citra Butterfly_mod.jpg

2. Kode program untuk Citra lena

rgblmage = imread ('Citra Lena.jpg'); 을 Sample image.

windowWidth = 13; \% Whatêver you want. More blur for larger

numbers. kernel = ones (windowWidth) / windowWidth $\wedge 2$;

blurredImage = imfilter(rgbImage, kernel); $\frac{\circ}{0}$ Blur the image.

imshow(blurredImage); $\frac{\circ}{\circ}$ Display it.

Dari kode program ini maka dihasilkan citra modifikasi sebagai berikut :

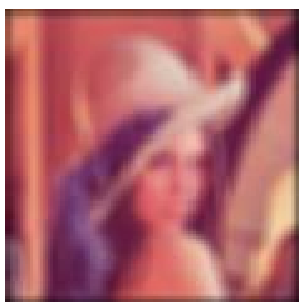

Gambar 4. Citra Lena_mod.jpg

Setelah citra asli mengalami blur, maka dilakukan proses penerapan filter Shen-Castan, filter CannyDeriche dan filter Madenda. Dimana nilai untuk parameter intensitas noise (nilai $\alpha$ ) berada di nilai $\alpha<$ 0 . Berikut adalah hasilnya penerapan ketiga filter tersebut :

1. Hasil penerapan filter pada citra butterfly

Berikut adalah tabel hasil penerapan filter pada citra butterfly : 
Tabel 2. Hasil Penerapan Filter pada citra Butterfly

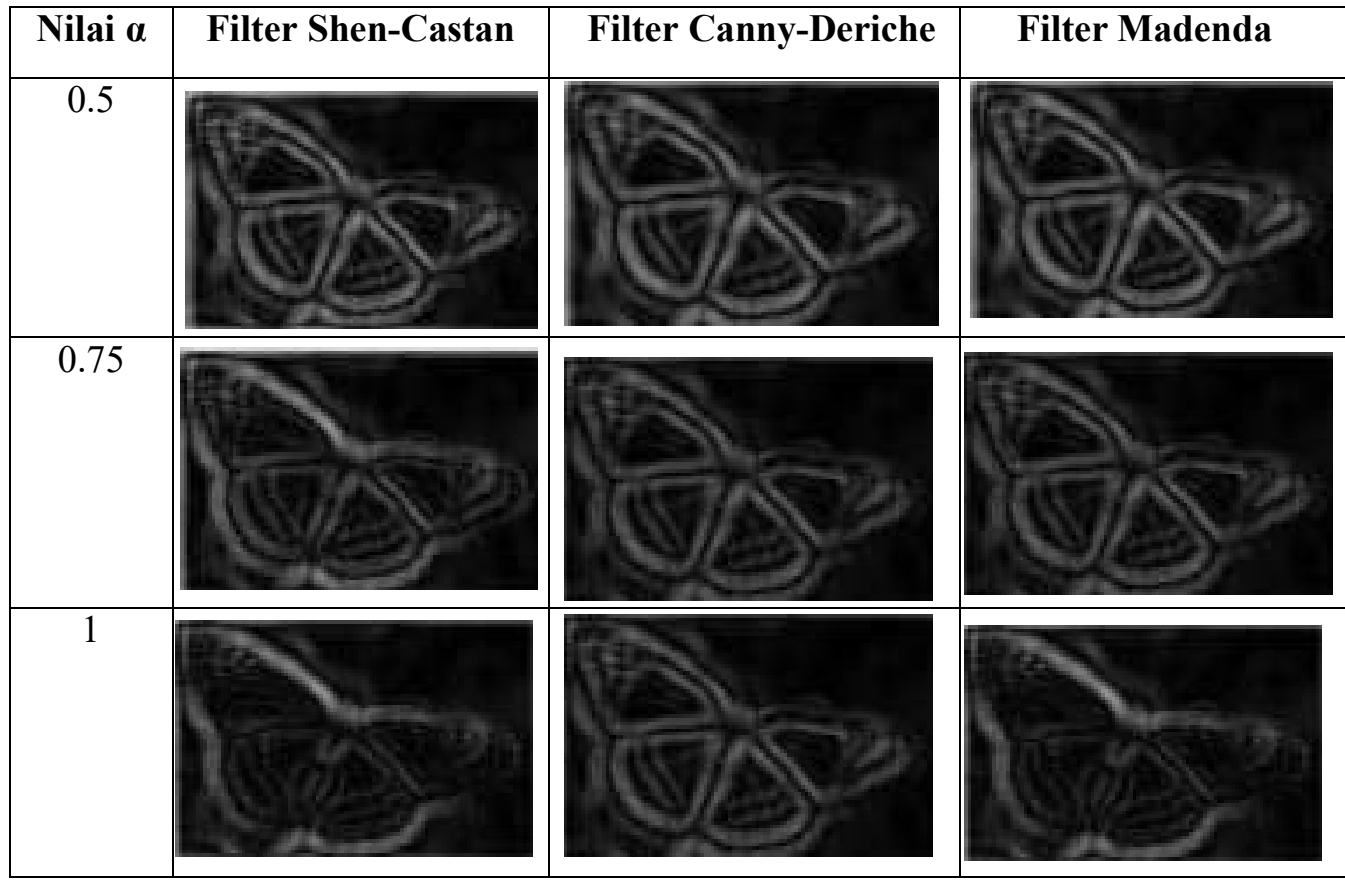

Dari tabel 2 di atas dapat dihasilkan :

1. Penerapan pseudo-code untuk filter Shen-Castan, filter Canny-Deriche dan filter Madenda dapat berhasil menghasilkan pendeteksian tepi pada citra yang menggalami gangguan noise.

2. Parameter $\alpha$ adalah parameter yang noise yang nilainya dapat diatur sesuai dengan seberapa besar tingkat kekasaran noise yang akan di filter. Nilai untuk parameter ini

untuk deteksi citra butterfly adalah $0.5,0.75$ dan 1 dikarenakan pada rentang nilai ini dapat terlihat perbedaan ukuran ketebalan dari deteksi tepi.

3. Pada nilai $\alpha=0.5$, ketiga filter, Baik filter Shen-Castan, filter Canny-Deriche maupun

filter Madenda, menghasilkan tepi yang hampir sama dengan aslinya.

4. Pada nilai $\alpha=0.75$, pada filter Shen-Castan menghasilkan tepi yang lebih tebal dari citra aslinya jika dibandingkan dengan filter Canny-Deriche dan filter Madenda.

5. Pada nilai $\alpha=1$, pada filter Shen-Castan dan filter Madenda menghasilkan beberapa tepi yang menghilang dibandingkan filter Canny-Deriche.

2. Hasil penerapan filter pada citra lena

Berikut adalah tabel hasil penerapan filter pada citra lena :

Tabel 3. Hasil Penerapan Filter pada citra lena

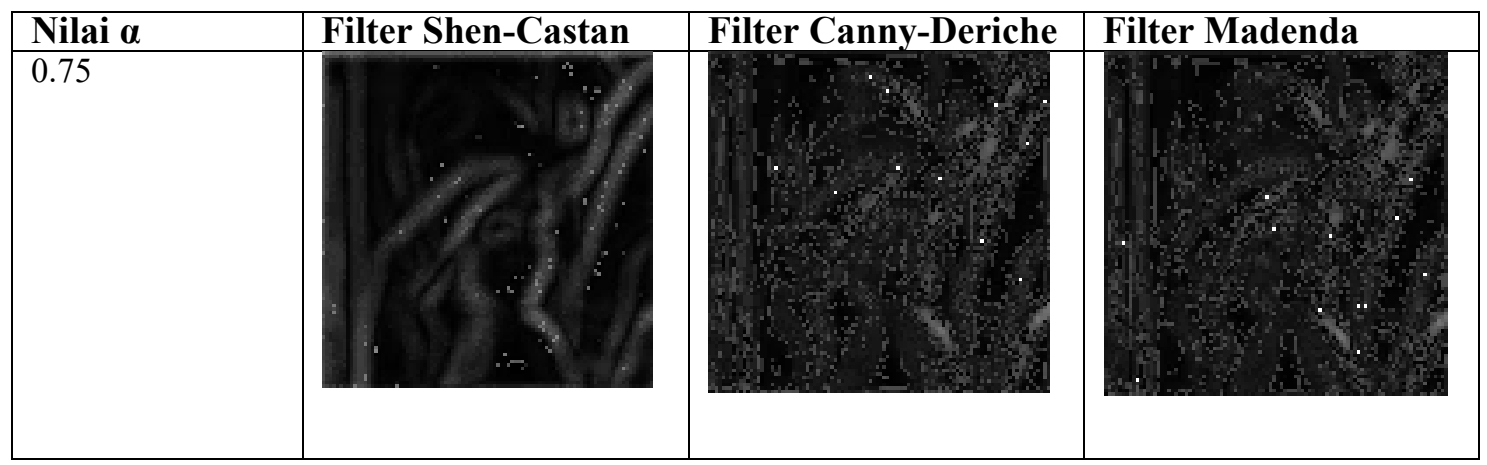




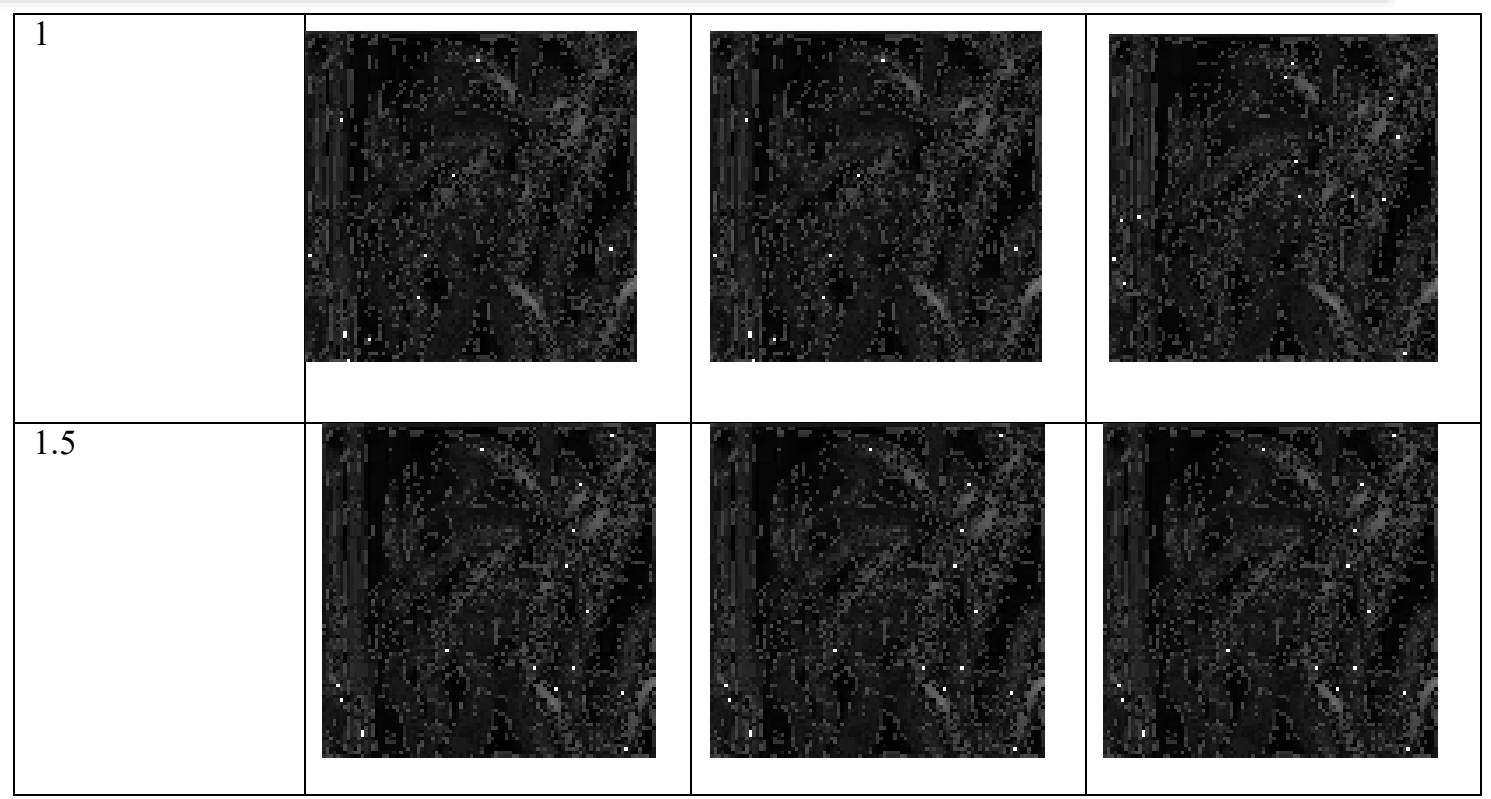

Dari tabel 3 di atas dapat dihasilkan :

1. Penerapan pseudo-code untuk filter Shen-Castan, filter Canny-Deriche dan filter Madenda dapat berhasil menghasilkan pendeteksian tepi pada citra yang menggalami gangguan noise.

2. Parameter $\alpha$ adalah parameter yang noise yang nilainya dapat diatur sesuai dengan seberapa besar tingkat kekasaran noise yang akan di filter. Nilai untuk parameter ini untuk deteksi citra lena adalah $0.75,1$ dan 1.5 dikarenakan pada rentang nilai ini dapat terlihat perbedaan ukuran ketebalan dari deteksi tepi.

3. Pada nilai $\alpha=0.5$, ketiga filter, Baik filter Shen-Castan, filter Canny-Deriche maupun filter Madenda, menghasilkan tepi yang hampir sama dengan aslinya.

4. Pada nilai $\alpha=0.75$, Filter Canny-Deriche memberikan hasil yang lebih halus jika

dibandingkan dengan filter lainnya.

5. Pada nilai $\alpha=1$, pada filter Shen-Castan dan filter Madenda menghasilkan beberapa tepi yang menghilang dibandingkan filter Canny-Deriche.

\section{KESIMPULAN}

Hasil dari penerapan filter pada citra yang mendapatkan gangguan noise dapat dilihat pada tabel 2 dan 3. Dari perbandingan ketiga filter tersebut menunjukkan bahwa filter Canny-Deriche dapat menghasilkan deteksi tepi yang lebih baik dibandingkan filter Madenda dan filter Shen-Castan dimana intensitas tepi objek lebih tinggi dibandingkan dengan intensitas noise yang terfilter.

Tabel 4. Kesimpulan Hasil Pengujian

\begin{tabular}{|c|c|c|}
\hline & \multicolumn{2}{|c|}{ Analisa Pengujian } \\
\hline Filter Shen-Castan & $\begin{array}{l}\text { Berhasil mendeteksi semua tepi citra, } \\
\text { ada beberapa bagian yang hilang. }\end{array}$ & $\begin{array}{l}\text { Tepi yang dihasilkan lebih tebal dari } \\
\text { citra aslinya }\end{array}$ \\
\hline Filter Canny-Deriche & Berhasil mendeteksi semua tepi citra & $\begin{array}{l}\text { Tepi yang dihasilkan lebih halus dari } \\
\text { citra aslinya. }\end{array}$ \\
\hline Filter Madenda & $\begin{array}{l}\text { Berhasil mendeteksi semua tepi citra, } \\
\text { ada beberapa bagian yang hilang }\end{array}$ & $\begin{array}{l}\text { Tepi yang dihasilkan lebih tebal dar } \\
\text { citra aslinya, ada beberapa tepi yang } \\
\text { justru menghilang. }\end{array}$ \\
\hline
\end{tabular}

Deteksi tepi merupakan salah satu tahapan awal dalam proses pengolahan citra. Perbandingan deteksi tepi antara filter Shen-Castan, filter Canny Derieche dan filter Madenda berhasil menghasilkan deteksi tepi cukup jelas walau dengan citra yang mengalami gangguan blur. 
Filter Canny-Deriche dan filter Madenda memiliki hasil deteksi tepi yang lebih baik dibandingkan filter Shen-Castan. Hasil deteksi tepi dari filter Canny-Deriche lebih halus dibandingkan filter Shen-Castan maupun filter Madenda.

\section{SARAN}

Pengembangan untuk penelitian selanjutnya untuk pendeteksian tepi pada citra yang mengalami gangguan blur dapat menggunakan filter yang lain, sehingga dapat membandingkan untuk mendapatkan filter yang paling baik. Macam dari nilai intensitas blur $(\alpha)$ dapat diberikan lebih banyak lagi varian sehingga sehingga dapat menghasilkan tingkat akurasi yang lebih baik.

\section{DAFTAR PUSTAKA}

[1]. Hidayatno, R. R. Isnanto, and B. Niam, "Analisis Deteksi Tepi Pada Citra Berdasarkan Perbaikan Kualitas Citra," Jur. Tek. Elektro Fak. Tek., no. January, 2011.

[2]. M. A. A. Hassan, A. Ibrahim, N. E. A. Khalid, and H. M. Noor, "Evaluation of Sobel, Canny, Shen \& Castan using sample line histogram method," Proc. - Int. Symp. Inf. Technol. 2008, ITSim, vol. 4, no. May 2014, 2008, doi: 10.1109/ITSIM.2008.4632072.

[3]. Supriyatin, "Perbandingan Metode Sobel, Prewitt, Robert dan Canny pada Deteksi Tepi Objek Bergerak," Ilk. J. Ilm., vol. 12, no. 2, pp. 112-120, 2020, doi: 10.33096/ilkom.v12i2.541.112120.

[4]. Madenda Sarifuddin, Pengolahan Citra \& Video Digital: Teori, Aplikasi dan Pemrograman Menggunakan MATLAB. Erlangga, Jakarta, 2015.

[5]. D. A. P. Hapsari, W. K. Nofa, and S. Santoso, "Analisis Kompleksitas Algoritma Filter IRR Shen-Castan untuk Deteksi Tepi pada Citra Digital," CCIT J., vol. 12, no. 2, pp. 218-228, 2019, doi: 10.33050/ccit.v12i2.693.

[6]. Hastuti, "Perbandingan Metode Deteksi Tepi Menggunakan Metode Canny, Prewitt Dan Sobel Pada Image Ikan," J. Repos. Poliban, vol. 5662, pp. 9-10, 2016.

[7]. D. A. Puspa Hapsari and W. K. Nofa, "Analisa Perbandingan Deteksi Tepi Pada Citra Digital Mengalami Blur Menggunakan Shen-Castan Dan Canny-Deriche," ICIT J., vol. 6, no. 2, pp. 205-212, 2020, doi: 10.33050/icit.v6i2.1117.

[8]. S. Santoso, D. A. P. Hapsari, and R. Susiloatmadja, "Complexity Analysis and Performance of the Madenda Filter Algorithm," Proc. 2019 4th Int. Conf. Informatics Comput. ICIC 2019, 2019, doi: 10.1109/ICIC47613.2019.8985821.

[9]. J. W. Yodha and A. W. Kurniawan, "Perbandingan Penggunaan Deteksi Tepi Dengan Metode Laplace, Sobel Dan Prewit Dan Canny Pada Pengenalan Pola," Techno.COM, vol. 13, no. 3, pp. 189-197, 2014. 